tion has got past the purely experimental stage; the author estimates that fumigants sufficient for a hundred thousand acres were produced in 1950, the chief being ethylene dibromide. As yet, the process is only warranted for high-value crops, and the eelworm population is checked rather than wipad out.

\section{THE BIRTH OF NEO-POSITIVISM}

\section{The Vienna Circle}

The Origin of Neo-Positivism; a Chapter in the History of Recent Philosophy. By Prof. Victor Kraft. 'Translated from the German 'Der Wiener Kreis' by Arthur Pap. Pp. xii + 209. (New York: Philosophical Library, Inc., 1953.) 3.75 dollars.

GOWEVER rapidly philosophical clima change, and whatever may prove to be the capricious nature of their characteristic cycles, there are certain epochs which will always stand out. One of them is assuredly that of the Vienna Circle. Postponing for the moment a more detailed consideration of its Lebenslauf, it is meanwhile worth recollecting that to many scholars in Great Britain it was always "Der Wiener Kreis", a sure token of affectionate regard ; and this in spite of a healthy determination to be the candid friend, avoiding like the plague all semblance of merely polite approval. Thus, as the author says, in Britain and in the United States its purpose found understanding and its tenets secured respect. Not so, however, in contemporary Germany, wherein many cross-currents (not all of them wholly fortuitous) combined to make very heavy weather for the evangelists of neo-positivism.

It is essential to see Prof. V. Kraft's book against such a background. Further, one may dislike the Circle's particular criterion of verifiability and its rather facile (and over-frequent) use of the adjective 'meaningless'-in fact, much of the stock-in-tradeand yet agree what great things it has accomplished. For this is a close-up view, not so much of the creed as of the people who fashioned it, and who passionately believed in it. For those reasons alone, a version in the English language is welcome. Would that-even allowing for its production on the western side of the Atlantic-it was a better version. Epistemological German is notoriously hard to translate, and even harder to make live; but ebenso, some of the text as it now appears is far from lovely, and moreover, many of the blemishes upon it are utterly needless.

The core of the volume consists of two long sections : logic and language, and empiricism. As might be expected, these form a commentary - and a very just one--upon the work of Carnap, Wittgenstein and their colleagues, on one hand, and of the critics on the other. The basic division is between the 'logic of science' and the special sciences. The latter are held to be concerned solely with questions of fact, to be validated by experience. Epistemology must have nothing to do with such things; its task is to deal with the logical structure of scientific knowledge. At the same time, philosophical method itself is required to conform to scientific principles.

Towards the end, we find a noble attempt to face up to the axiological import of the Vienna Circle's outlook. Obviously, it was heavily conditioned by a reaction against German metaphysics. Yet, conceptual poetry and even personal wisdom are not denied : upraised on their own pedestal they stand, but qualified as subjective and unverifiable in that they lack universal validity, and therefore the title, to represent knowledge.

Nobody can rightly quarrel with such a statement, the result of years of labour, thrust and counter-thrust by honest men engaged in the quest for truth. But they themselves would be reluctant to claim that the last word had been spoken: the Circle has been disrupted and its members scattered, some luckily to find shelter in calmer waters. Down the years, too, death has taken a heavy toll, but the search goes on, at once courageous (sometimes perhaps almost foolhardy) and relentless.

F. I. G. RAWLINS

\section{BENJAMIN THOMPSON, COUNT RUMFORD}

\section{An American in Europe}

The Life of Benjamin Thompson, Count Rumford. By Egon Larsen. Pp. 224+28 plates. (London: Rider and Co., Ltd., 1953.) 15s. net.

7 HIS book is described by the publishers as "the first popular yet authoritative biography" of Benjamin Thompson, Count Rumford, and its publication was timed to coincide with the bicentenary in March 1953 of his birth. It is a very readable short account of his life and activities, or certain aspects of them. Mr. E. Larsen has been at great pains to collect information in the various places where Rumford lived and worked, and we are indebted to him for some new and interesting particulars - for example, the information on the laying out and subsequent history of the English garden in Munich and that on the house at Auteuil which was Rumford's last home. Some of the illustrations, which are-good, are from photographs by the author.

It is not a book to go to for an estimate of Rumford's achievements as a man of seience. The references to his fundamental researches on heat are scanty, and the author has not attempted anything in the nature of a connected account of his scientific work. There is a fuller and more satisfactory treatment of his measures of reform in Bavaria, his work for the poor in Munich, and the methods of fuel economy and designs of stoves and fireplaces which he introduced in his workhouses and military establishments. Emphasis is rightly given to his pioneering efforts in the application of scientific principles to purposes of this kind.

A chapter is devoted to his later period in England and his activities in connexion with the founding of the Royal Institution. At the end of the book a well-chosen series of extracts from Rumford's essays, indicating the varied nature of his interests, extends to some forty pages.

It is, however, on a personal and biographical thread that this book hangs, and if the treatment of such matters as Rumford's relations with his daughter and with his second wife, the widow of Lavoisier, is somowhat journalistic, it is none the less interesting. Biographical writing on Rumford begins with Ellis's invaluable "Memoir", published in 1876, and, although much has been written since, the character of the man remains in certain respects somewhat shadowy. In his more personal affairs he covered up his tracks, and the impression persists that the full story of his life has yet to be written.

T. MARTIN 